\title{
Influence of pre-harvest bagging on fruit quality of mango (Mangifera indica L.) cv. Mollika
}

\author{
M. T. Islam ${ }^{1}$, M. Shamsuzzoha' ${ }^{2}$ M. S. Rahman ${ }^{3}$, M. M. Haque ${ }^{4}$ and R. Alom ${ }^{5}$ \\ ${ }^{1}$ Dept. of Horticulture, Hajee Mohammad Danesh Science and Technology University, Dinajpur 5200 \\ Dept. of Chemistry, Hajee Mohammad Danesh Science and Technology University, Dinajpur 5200 \\ ${ }^{3}$ Dept. of Agricultural Chemistry, Hajee Mohammad Danesh Science and Technology University, \\ Dinajpur 5200 \\ ${ }^{4}$ Dept. of Biochemistry, Hajee Mohammad Danesh Science and Technology University, Dinajpur 5200, \\ ${ }^{5}$ Dept. of Crop Physiology and Ecology, Hajee Mohammad Danesh Science and Technology University, \\ Dinajpur 5200, Bangladesh
}

$₫$ For any information: ask.author@journalbinet.com, Received: 02.08.17, Revised: 04.10.17;

Available online: 14 October 2017.

\begin{abstract}
An investigation was performed for safe mango production by applying minimum use of pesticide, entitled studies on influence of bagging on physico-chemical properties and shelf life of mango cv. Mollika. Mango fruits were bagged at marble stage with different types of bags which constituted various treatments viz.: $T_{1}$ : Brown paper double layered bag (BPB), $T_{2}$ : White paper single layered bag (WPB), T3: Muslin cloth bag (MCB) and $T_{0}:$ Non-bagged (control). Bagging with brown paper bag and white paper bag improved fruit retention, weight of fruit, diameter of fruit, pulp weight, total soluble solids, ascorbic acid, percent of citric acid, reducing sugars and $\beta$-carotene at harvest and ripe stage over control. Brown paper bag improved fruit color, texture, appearance and sweetness. In all cases, good quality, cleaner, disease and insect free fruits were harvested. The sensory qualities in fruits of brown, white and muslin cloth bags were improved over control. Fruits treated with brown paper bag showed shelf life upto 18 days with lowest weight loss and good physical quality as against 15 days of untreated fruits (control). Pre-harvest bagging also reduced occurrence of spongy tissue and the incidence of mealy bugs. Thus it is concluded that fruit bagging influenced growth and development of mango fruit by the reductionof disease and insect-pest attack and also increases shelf life of mango.
\end{abstract}

Key Words: Mango, Bagging materials, Physico-chemical composition and Sensory evaluation

Cite Article: Islam, M. T., Shamsuzzoha, M., Rahman, M. S., Haque, M. M. and Alom, R. (2017). Influence of pre-harvest bagging on fruit quality of mango (Mangifera indica L.) cv. Mollika. Journal of Bioscience and Agriculture Research,15(01), 1246-1254.

Crossref: https://doi.org/10.18801/jbar.150117.153

Article distributed under terms of a Creative Common Attribution 4.0 International License.

\section{Introduction}

Mango (Mangifera indica L.) is one of the most important fruit crops in Bangladesh covering the largest area (50,000 ha.) and the total production (1,90,000 tons) being in the 3rd position after 
banana and jackfruit (Bhuyan et al., 2003). It belongs to the family Anacardiaceae and genus Mangifera and also acknowledged as the "king of fruits"(Singh, 1996). Mango is known as one of the choicest and well accepted fruits all over the world due to its taste, fascinating flavor, eye-catching color andtypical nutritive value. It also helps in balancing the human diet by providing about 64-86 calories per 100 grams of ripe fruits (Rathore et al., 2007). It is a good source of vital protective nutrients like vitamin A, B and C, niacin and alsorich in minerals including calcium,potassium and iron (Amin and Hanif, 2002). The ripe fruits are also utilized forprocessing of several products like readytoserve, nectar, squash, panna, syrup, mongo leather, mango powder, flakes, toffee, jams and jelly.

Now a day, among various reasons for the impaired production of mango, the attack of insect pests and diseases is of particular importance. So, fruit bagging technology is being promoted in mango orchards in northwest region commercially during the pre-harvest season to protect mango from pest attack besides facilitating the farmers to get quality yield. It is done to prevent damage occurring due to bruises, wounds, scars, diseases, pest attack and to produce cleaner fruit skin with attractive colour (Bayogan et al., 2006). Bagging increased fruit weight and peel colour development from green to yellow, due to less chlorophyll a and chlorophyll b. Regarding the fruit weight, 2-layer bagged fruit had the highest weight (Watanawan et al., 2008). The practice of pre-harvest bagging has been extensively used in several fruit crops to improve skin colour and to reduce splitting (Song and Song, 1993), mechanical damage (Amarante et al., 2002), and sunburn (Bentley and Viveros, 1992) of the skin. Preharvest bagging also reduces agrochemical residues in the fruit (Amarante et al., 2002) and improves insect (Bentley and Viveros, 1992) disease (Hofman et al., 1997) and bird damage control. Several authors have reported contradictory results for the effects of pre-harvest bagging on fruitsize, maturity and mineral contentat harvest for different fruits. This may reflect differences in the type of bag used, fruit stage when it was bagged, duration of fruit exposure to natural light after bag removal (before harvesting), and/or fruit and cultivar specific responses (Hofman et al., 1997). This study investigated the impact of bagging of mango fruit (Mangifera indica L.) cv. Mollika with different type of bags on fruit growth, maturity at harvest, mineral content, skin permeance, and storage behaviour. Therefore, the present study was undertaken to compare the efficacy of different bagging materials for getting quality mango.

\section{Materials and Methods}

This research was conducted at the Department of Horticulture, HSTU, Dinajpur, Bangladesh during January to July, 2016. Uniformly grown 10 years old Mollika mango grafted trees was selected. The experiment was constructed in Randomized Block Design with five treatments replicated three times with a unit of 50 fruits per treatment per replication. Different types of bags were constituted the treatments viz.: $\mathrm{T}_{1}$ : Brown paper double layered bag (BPB), $\mathrm{T}_{2}$ : White paper single layered bag (WPB), $\mathrm{T}_{3}$ : Muslin cloth bag (MCB) and $\mathrm{T}_{0}$ : Non-bagged (control). Uniformly grown fruits (40 to 50 days after fruit set) were selected for bagging. The sizes of bags were $25 \times 20 \mathrm{~cm}$. Before bagging two perforations ( $\leq 4 \mathrm{~mm}$ diameter) was made for proper ventilation at the bottom of polythene bag and muslin cloth bag. White and brown paper bags were not perforated. The particular bags were wrapped properly at the stalk of each fruit of respective treatments so that it would not be fall down as well as there would not be open space. The observations viz. fruit retention (\%) and day's require for harvesting after bagging were recorded. Four fruits were randomly selected per treatment per replication to record various physical and chemical compositions which were estimated by the following procedures:

Physical parameters: Length and diameter of fruit were measured with the help of digital varner caliper and expressed in centimeters $(\mathrm{cm})$. Weight of fruit, pulp and stone was recorded by using electronic balance and expressed in grams (g).

Chemical composition: Total soluble solid (TSS), total soluble solids were found out by using Erma Hand Refract meter $\left(0\right.$ to $32^{\circ}$ Brix) and expressed in ${ }^{\circ}$ Brix (AOAC, 2004).

Citric acid (\%): $10 \mathrm{~g}$ mango pulp was crushed in a mortar and pestle and transferred in a $100 \mathrm{ml}$ volumetric flask. Volume was made up to $100 \mathrm{ml}$ by distilled water. Then the sample was filtered and $10 \mathrm{ml}$ filtrate was taken in a conical flask. The filtrated was titrated against $0.1 \mathrm{~N} \mathrm{NaOH}$ using 
phenolphthalein as an indicator. The results were expressed in percent of citric acid (Moffet et al., 2007).

$\%$ Citric acid $=\frac{0.5 \times \text { Titrate value unknown soln } \times \text { Made volume of unknown sample }}{\text { Titrate value of known soln } \times \text { Aliquot taken } \times \text { Wt.of sample }} 100$

Reducing sugar (\%): It was determined according to the method described by (Haq and Rab, 2012) and (Santini et al., 2014) with slight modification. Crushing $20 \mathrm{~g}$ of the mango pulp was transferred in a $200 \mathrm{ml}$ volumetric flask. The volume was adjusted to $150 \mathrm{ml}$ by purified water. After a few minutes, $10 \mathrm{ml}$ of lead acetate solution and the minimum amount of potassium oxalate solution were added to allow the sugar dissolution. The volume of the resulting solution was adjusted to $200 \mathrm{ml}$, and was shaked, filtered and transferred in a burette for the titration. This extraction is titrated against Fehling solutions with the help of methylene blue indicator.

$$
\% \text { Reducing sugar }=\frac{\text { Fehling factor } \times \text { Dilution } \times 100}{\text { Titre } \times \text { weight or volume of sample }}
$$

Total sugar: An aliquot of $50 \mathrm{ml}$ of the clarified, de-leaded filtrate was pipetted to a $100 \mathrm{ml}$ volumetric flask, $5 \mathrm{ml}$ conc. $\mathrm{HCl}$ was added and allowed to stand at room temperature for 24 hours. It was neutralized with conc. $\mathrm{NaOH}$ solution followed by $0.1 \mathrm{~N} \mathrm{NaOH}$ solutions. The volume was made upto the mark and transferred to $50 \mathrm{ml}$ burette having an offset tip and performed the titration on Fehlings solution (AOAC, 2000).

$$
\% \text { Total sugar }=\frac{\text { Fehling factor } \times \text { Dilution } \times 100}{\text { weight of sample } \times \text { Titre }}
$$

Ascorbic acid (mg/100g of Fruit pulp): Ascorbic acid was estimated as described by (McHenry and Graham, 1935)Mango pulp (5g) was mixed with $5 \mathrm{ml}$ of $20 \%$ metaphosphoric acid solution and filtered. The filtrate $(5 \mathrm{ml})$ was put in a small beaker and shaken with 2 drops of phenolphthalein solution and titrated against 2, 6-indophenol until pink color developed.

$$
\text { Vit C }(\mathrm{mg} / 100 \mathrm{~g})=\frac{0.5 \times \text { Titrate value unknown soln } \times \text { Made volume of unknown sample }}{\text { Titrate value of known soln } \times \text { Aliquot taken } \times \text { Sample weight }}
$$

$\boldsymbol{\beta}$-Carotene ( $\boldsymbol{\mu g} / \mathbf{1 0 0} \mathrm{g}$ of pulp): $\beta$-carotene in mango pulp was determined according to the method of (Nagata and Yamashita, 1992) . One gram of pulp was mixed with $10 \mathrm{ml}$ of acetone: hexane mixture (4: 6) and vortex for 5 minutes. The mixture was filtered and absorbance was measured at 453nm, $505 \mathrm{~nm}$ and $663 \mathrm{~nm}$.

$$
\beta \text {-carotene }(\mathrm{mg} / 100 \mathrm{ml})=0.216 \mathrm{~A}_{663}-0.304 \mathrm{~A}_{505}+0.452 \mathrm{~A}_{453}
$$

Shelf life of fruits (Days): Mature fruits were harvested at 80-85 percent maturity. Twenty harvested mature fruits of each treatment were ripened at ambient temperature by using plastic crates with perforation and traditional paddy straw as ripening material. At the bottom, $2.5 \mathrm{~cm}$ layer of paddy straw was made on which fruits were arranged. Simultaneously, two more layers were kept on the first layer. After ripening the various observations viz. shelf life (days) and incidence of mealy bug (\%) were recorded. The end of shelf life was noted when the fruits were spoiled.

The ripe fruits were also examined for their sensory qualities for assessing color, flavor and texture by panel of five judges with nine point Hedonic Scale viz. 1-Dislike extremely, 2-Dislike very much, 3Dislike moderately, 4-Dislike slightly, 6-Like slightly, 7-Like moderately, 8-Like very much and 9-Like extremely (Amerine et al., 1965).

The data were analysed by Duncan's multiple range test (DMRT) at $P<0.05$. All statistical procedures were conducted using SPSS 22.0 for Windows (SPSS Inc., Chicago, IL, USA). 


\section{Results and Discussion}

\section{Fruit retention (\%) and harvesting time (days)}

Fruit retention was non-significantly improved by pre-harvest bagging with brown paper bag (80.60 $\%)$ and white paper bag (80.00\%) over control (75.00\%). The fruit retention found in muslin cloth bag was $(78.00 \%)$ (Table 01$)$. The harvesting time was significantly delayed (72 days) in brown paper bag as well as muslin cloth bag over white paper bag (71 days). The control took minimum days (70 days) for harvest (Table 01).

Table 01. Effects of pre-harvest fruit bagging on fruit retention and days required for harvesting after bagging in mango fruit cv. Mollika

\begin{tabular}{lll}
\hline Treatments & Fruit retention (\%) & Days required for harvesting after bagging \\
\hline Brown paper bag & $80.60 \pm 0.60 \mathrm{a}$ & $72 \pm 0.58 \mathrm{a}$ \\
White paper bag & $80.00 \pm 0.58 \mathrm{a}$ & $71 \pm 0.58 \mathrm{a}$ \\
Muslin cloth bag & $78.00 \pm 0.58 \mathrm{~b}$ & $72 \pm 0.58 \mathrm{a}$ \\
No bagging (control) & $75.00 \pm 0.58 \mathrm{c}$ & $70 \pm 0.58 \mathrm{a}$ \\
\hline \multicolumn{2}{l}{ zMeans \pm standard error within a column followed by different letter(s) are significantly different (DMRT, $\mathrm{p}$} \\
$<0.05$ ).
\end{tabular}

\section{Fruit weight (\%)}

The fruits of Muslin cloth bag produced the biggest fruit having fruit weight (361.00 g) while in brown paper bag having fruit weight (342.76 g). The fruit weight found in white paper bag (325.76 g) also higher than control but the differences were non-significant. However, minimum fruit weight was recorded in the treatment of control (323.14 g) (Table 02). These findings are accordance with some previous reports that the effects of pre-harvest bagging increased fruit growth, size, and weight (Sharma et al., 2014; Yang et al., 2009; Zhou et al., 2012). Bagging 'Nam Dok Mai 4' mango fruit with two-layer paper bags, newspaper, or golden paper bags increased fruit weight. (Watanawan et al., 2008). Bagging increased fruit weight, size over control fruits (Chonhenchob et al., 2011). Bagging promoted longan fruit development, resulting in larger-sized fruit (Yang et al., 2009). Microenvironment created by different bagging materials might have congenial effect on fruit growth of mango.

\section{Fruit length (cm)}

The treatment of brown paper bag and muslin cloth bag were gave the maximum fruit length (11.39 $\mathrm{cm}$ and $11.36 \mathrm{~cm}$ respectively). The fruit length found in white paper bag $(11.03 \mathrm{~cm})$ also higher than control but the differences were non-significant. However, minimum fruit length was recorded in the treatment of control $(10.65 \mathrm{~cm})$ (Table 02).

Table 02. Effects of pre-harvest fruit bagging on physical parameters of mango cv. Mollika

\begin{tabular}{lllllll}
\hline $\begin{array}{l}\text { Treat } \\
\text {-ments }\end{array}$ & $\begin{array}{l}\text { weight of fruit } \\
(\mathrm{g})\end{array}$ & $\begin{array}{l}\text { Length of } \\
\text { fruit }(\mathrm{cm})\end{array}$ & $\begin{array}{l}\text { Diameter of } \\
\text { fruit }(\mathrm{cm})\end{array}$ & $\begin{array}{l}\text { Pulp weight } \\
(\mathrm{g})\end{array}$ & $\begin{array}{l}\text { Stone weight } \\
(\mathrm{g})\end{array}$ & $\begin{array}{l}\text { Pulp:Stone } \\
\text { ratio }\end{array}$ \\
\hline $\begin{array}{l}\text { Brown } \\
\text { paper bag }\end{array}$ & $\begin{array}{l}342.76 \pm 4.95 \\
\mathrm{ab}\end{array}$ & $11.39 \pm 0.31 \mathrm{a}$ & $8.36 \pm 0.33 \mathrm{a}$ & $271.79 \pm 4.39 \mathrm{a}$ & $32.11 \pm 0.58 \mathrm{c}$ & $8.46 \pm 0.05 \mathrm{a}$ \\
$\begin{array}{l}\text { White } \\
\text { paper bag }\end{array}$ & $325.76 \pm 2.98 \mathrm{~b}$ & $11.03 \pm 0.04 \mathrm{a}$ & $7.95 \pm 0.03 \mathrm{a}$ & $244.30 \pm 2.31 \mathrm{~b}$ & $36.84 \pm 0.91 \mathrm{~b}$ & $6.63 \pm 0.12 \mathrm{~b}$ \\
$\begin{array}{l}\text { Muslin } \\
\text { cloth bag }\end{array}$ & $\begin{array}{l}361.00 \pm 18.20 \\
\mathrm{a}\end{array}$ & $11.36 \pm 0.21 \mathrm{a}$ & $8.49 \pm 0.10 \mathrm{a}$ & $\begin{array}{l}268.38 \pm 10.4 \mathrm{a} \\
\mathrm{b}\end{array}$ & $41.10 \pm 0.88 \mathrm{a}$ & $6.54 \pm 0.33 \mathrm{~b}$ \\
$\begin{array}{l}\text { No } \\
\text { bagging }\end{array}$ & $323.14 \pm 3.14 \mathrm{~b}$ & $\begin{array}{l}10.65 \pm 0.32 \\
\mathrm{a}\end{array}$ & $7.95 \pm 0.03 \mathrm{a}$ & $\begin{array}{l}259.90 \pm 10.3 \mathrm{a} \\
\mathrm{b}\end{array}$ & $39.13 \pm 0.84 \mathrm{ab}$ & $6.65 \pm 0.34 \mathrm{~b}$ \\
\hline
\end{tabular}

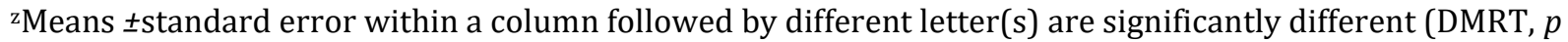
$<0.05)$. 


\section{Fruit diameter (cm)}

Pre-harvest fruit bagging with muslin cloth bag $(8.49 \mathrm{~cm})$ gave the maximum fruit diameter over white paper bag $(7.95 \mathrm{~cm})$ while control $(7.95 \mathrm{~cm})$ gave the minimum fruit diameter (Table 02).

\section{Pulp weight (g)}

The treatment with brown paper bag (271.79 g) had significantly highest pulp weight over control ( $259.90 \mathrm{~g}$ ) while the white paper bag gave the minimum ( $244.30 \mathrm{~g}$ ). The pulp weight was found in the treatment of muslin cloth bag (268.38 g) which is over than no bagging (Table 02).

\section{Stone weight (g)}

The maximum stone weight ( $41.10 \mathrm{~g}$ ) was recorded in the treatment of muslin cloth bag over control (39.13 g). The treatments white paper bag (36.84 g and brown paper bag (32.11) were also over than control. The minimum stone weight (20.20 g) was recorded in the treatment of brown paper bag (Table 02).

\section{Pulp stone ratio}

The treatment of brown paper bag (8.46) gave the maximum pulp stone ratio than control (6.65).There was non-significant difference among the rested treatments. Pre-harvest bagging with different bags recorded superior pulp to stone ratio over control fruits (Haldankar et al., 2015).

\section{Ascorbic acid (mg/100 g)}

The highest ascorbic acid content was recorded in the treatment of no bagging $(68.81 \mathrm{mg} / 100 \mathrm{~g})$ while the lowest was recorded in the brown paper bag $(46.51 \mathrm{mg} / 100 \mathrm{~g})$ (Table 03). The bagged fruits recorded highest content of vitamin $\mathrm{C}$, sucrose, glucose and fructose over control in Zill mango (Hongxia et al., 2009). The above results are very close to the findings of (Haldankar et al., 2015) and (Sharma et al., 2013) in mango.

Table 03. Effects of pre-harvest fruit bagging on chemical composition of mango cv. Mollika at harvest

\begin{tabular}{lllllll}
\hline Treatments & $\begin{array}{l}\text { Ascorbic } \\
\text { acid } \\
(\mathrm{mg} / 100 \mathrm{~g})\end{array}$ & TSS $\left({ }^{\circ} \mathrm{Brix}\right)$ & Citric acid (\%) & $\begin{array}{l}\text { Reducing } \\
\text { sugars }(\%)\end{array}$ & $\begin{array}{l}\text { Total sugars } \\
(\%)\end{array}$ & $\begin{array}{l}\beta \text {-carotene } \\
(\mu \mathrm{g} / 100 \mathrm{~g})\end{array}$ \\
\hline $\begin{array}{l}\text { Brown paper } \\
\text { bag }\end{array}$ & $\begin{array}{l}46.51 \pm 0.02 \\
\mathrm{~d}\end{array}$ & $8.67 \pm 0.02 \mathrm{a}$ & $20.97 \pm 0.00 \mathrm{~d}$ & $0.59 \pm 0.02 \mathrm{a}$ & $1.13 \pm 0.03 \mathrm{a}$ & $527.10 \pm 0.35 \mathrm{~b}$ \\
$\begin{array}{l}\text { White paper } \\
\text { bag }\end{array}$ & $\begin{array}{l}66.51 \pm 0.03 \\
\mathrm{~b}\end{array}$ & $6.37 \pm 0.02 \mathrm{~b}$ & $32.26 \pm 0.03 \mathrm{a}$ & $0.60 \pm 0.03 \mathrm{a}$ & $1.18 \pm 0.03 \mathrm{a}$ & $332.50 \pm 0.23 \mathrm{c}$ \\
$\begin{array}{l}\text { Muslin cloth } \\
\text { bag }\end{array}$ & $61.39 \pm 0.02 \mathrm{c}$ & $6.23 \pm 0.04 \mathrm{ac}$ & $27.42 \pm 0.03 \mathrm{c}$ & $0.54 \pm 0.04 \mathrm{a}$ & $0.94 \pm 0.02 \mathrm{~b}$ & $209.90 \pm 0.29 \mathrm{~d}$ \\
No bagging & $68.81 \pm 0.02 \mathrm{a}$ & $5.99 \pm 0.01 \mathrm{~d}$ & $31.78 \pm 0.01 \mathrm{~b}$ & $0.51 \pm 0.02 \mathrm{a}$ & $0.89 \pm 0.01 \mathrm{~b}$ & $563.80 \pm 0.11 \mathrm{a}$ \\
\hline
\end{tabular}

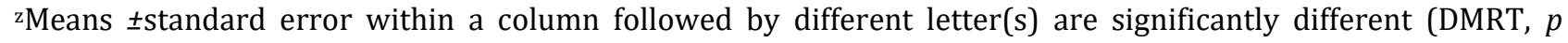
$<0.05)$.

\section{Total soluble solid (\% Brix)}

At harvest stage, the significantly highest soluble solids content was recorded in brown paper bag and white paper bag fruits (8.67 \% Brix and $6.37 \%$ Brix, respectively) over the rest of treatments (Table 03). At ripe stage, the fruits of muslin cloth bag and white paper bag showed the highest soluble solids content (21.43\% Brix and $20.17 \%$ Brix, respectively) while lowest total soluble solids was recorded in brown paper bag (17.00 \% Brix) (Table 04). The findings revealed that percent total soluble solids increased sharply from harvest to ripe fruits have got support of (Joshi and Roy,1988) who mentioned that TSS increase initially and declined later on. Similar finding was recorded in some previous studies (Haldankar et al., 2015; Awad, 2007; Singh et al., 2007). 
Table 04. Effects of pre-harvest fruit bagging on chemical composition of mango cv. Mollika at ripe stage

\begin{tabular}{lllllll}
\hline Treatments & $\begin{array}{l}\text { Ascorbic acid } \\
(\mathrm{mg} / 100 \mathrm{~g})\end{array}$ & TSS (B.Bix) & $\begin{array}{l}\text { Citric acid } \\
(\%)\end{array}$ & $\begin{array}{l}\text { Reducing } \\
\text { sugars }(\%)\end{array}$ & $\begin{array}{l}\text { Total } \\
\text { sugars }(\%)\end{array}$ & $\begin{array}{l}\beta \text {-carotene } \\
(\mu \mathrm{g} / 100 \mathrm{~g})\end{array}$ \\
\hline $\begin{array}{l}\text { Brown } \\
\text { paper bag }\end{array}$ & $41.14 \pm 0.03 \mathrm{~b}$ & $17.00 \pm 0.02 \mathrm{~d}$ & $11.72 \pm 0.03 \mathrm{a}$ & $1.06 \pm 0.02 \mathrm{c}$ & $\begin{array}{l}17.79 \pm 13.1 \\
\mathrm{a}\end{array}$ & $3164.33 \pm 0.07 \mathrm{a}$ \\
$\begin{array}{l}\text { White } \\
\text { paper bag }\end{array}$ & $26.85 \pm 0.04 \mathrm{c}$ & $20.17 \pm 0.02 \mathrm{~b}$ & $8.96 \pm 0.03 \mathrm{~b}$ & $1.41 \pm 0.02 \mathrm{a}$ & $3.84 \pm 0.03 \mathrm{a}$ & $2449.00 \pm 0.27 \mathrm{c}$ \\
$\begin{array}{l}\text { Muslin } \\
\text { cloth bag }\end{array}$ & $41.71 \pm 0.01 \mathrm{a}$ & $21.43 \pm 0.03 \mathrm{a}$ & $5.52 \pm 0.05 \mathrm{~d}$ & $0.93 \pm 0.03 \mathrm{~d}$ & $2.94 \pm 0.03 \mathrm{a}$ & $2922.13 \pm 0.13 \mathrm{~b}$ \\
& & & & & & \\
No bagging & $41.71 \pm 0.03 \mathrm{a}$ & $17.73 \pm 0.03 \mathrm{c}$ & $6.91 \pm 0.02 \mathrm{c}$ & $1.18 \pm 0.03 \mathrm{~b}$ & $3.42 \pm 0.03 \mathrm{a}$ & $1774.10 \pm 0.03 \mathrm{~d}$ \\
\hline
\end{tabular}

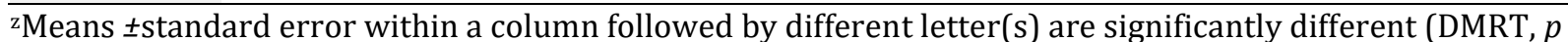
$<0.05)$.

\section{Citric acid (\%)}

The significantly maximum citric acid content at harvest stage was recorded in the white paper bag fruits treatment $(32.26 \%)$ while the minimum was recorded in the treatment of brown paper bags $(20.97 \%)$ (Table 03). During ripe stage, maximum citric acid content was recorded in the treatment of brown paper bag while the minimum content of citric acid was recorded in muslin cloth bag fruit (5.52 \%) (Table 04). The findings revealed that percent of citric acid decreased sharply from harvest to ripe fruits have got support by (Hiratsuka et al., 2012). They reported that organic acid content was reduced in Mandarin due to pre-harvest bagging.

\section{Reducing sugars (\%)}

The highest reducing sugars at harvest stage were recorded in white paper bag $(0.60 \%)$ over brown paper bag fruits $(0.59 \%)$ while the lowest was recorded in control $(0.51 \%)$ (Table 03). During ripe stage, the highest reducing sugars were recorded in white paper bag (1.41\%) while the lowest was recorded in muslin cloth bags (0.93\%) (Table 04). Similar findings were found in some previous research (Haldankar et al., 2015). They reported that fruits of newspaper bag exhibited the maximum reducing sugars at ripe stage in mango and soluble sugar was increased in grape due to pre-harvest bagging treatments.

\section{Total sugar (\%)}

At harvest stage, the significantly maximum total sugar was recorded in the fruits of white paper bag $(1.79 \%)$ over other bagging treatments and control while the minimum total sugar was recorded in the control fruits $(0.89 \%)$ (Table 03). During ripe stage, the fruits of brown paper bag exhibited maximum total sugar $(17.79 \%)$ while the minimum total sugar was recorded in the muslin cloth bag fruits (2.94\%) (Table 04) This result was confirmed with (Haldankar et al., 2015). They reported that brown paper bag with polythene coating $(7.48 \%)$ recorded the maximum total sugars in mango which was significant.

\section{$\beta$-carotene $(\mu \mathrm{g} / 100 \mathrm{~g})$}

The significantly highest $\beta$-carotene content at harvest stage was control (563.80 $\mu \mathrm{g}$ )and ripe stage

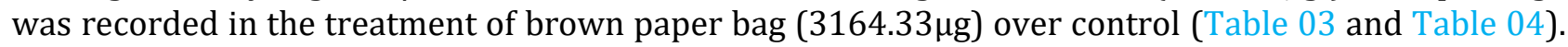
These findings are accordance with previous reports that a flesh lycopene and $\beta$-carotene content was increased due to pre-harvest bagging treatments in mango (Haldankar et al., 2015; Wang et al., 2006; Zhao et al., 2013).

A way to get better final mango quality traits such as size, colour, taste, nutritional value and flavour is also to build an integrated approach that links the two categories of factors, preharvest and postharvest, which influence the various components of mango quality. Brown paper bag helps to 
improve colour, texture, appearance, sweetness and flavor over control (no bagging). The overall impression found at brown paper bag was 9.00 (Table 05).

Table 05. Effect of pre-harvest fruit bagging on sensory evaluation in fruits of mango cv. Mollika at ripe stage

\begin{tabular}{lllllll}
\hline Treatments & Colour & Flavour & Texture & Appearance & Sweetness & $\begin{array}{l}\text { Overall } \\
\text { impression }\end{array}$ \\
\hline $\begin{array}{l}\text { Brown paper } \\
\text { bag }\end{array}$ & $8.33 \pm 0.33 \mathrm{a}$ & $7.67 \pm 0.33 \mathrm{a}$ & $7.67 \pm 0.33 \mathrm{a}$ & $8.67 \pm 0.33 \mathrm{a}$ & $8.00 \pm 0.58 \mathrm{a}$ & $9.00 \pm 0.00 \mathrm{a}$ \\
$\begin{array}{l}\text { White paper } \\
\text { bag }\end{array}$ & $7.00 \pm 0.00 \mathrm{~b}$ & $8.67 \pm 0.33 \mathrm{a}$ & $7.67 \pm 0.33 \mathrm{a}$ & $7.67 \pm 0.33 \mathrm{ab}$ & $8.00 \pm 0.33 \mathrm{a}$ & $7.66 \pm 0.33 \mathrm{a}$ \\
$\begin{array}{l}\text { Muslin cloth } \\
\text { bag }\end{array}$ & $7.00 \pm 0.00 \mathrm{~b}$ & $8.67 \pm 0.33 \mathrm{a}$ & $7.67 \pm 0.33 \mathrm{a}$ & $6.67 \pm 0.33 \mathrm{bc}$ & $7.33 \pm 0.33 \mathrm{a}$ & $7.33 \pm 0.33 \mathrm{a}$ \\
\begin{tabular}{l} 
No bagging \\
\hline
\end{tabular} & $7.00 \pm 0.00 \mathrm{~b}$ & $8.67 \pm 0.33 \mathrm{a}$ & $7.67 \pm 0.33 \mathrm{a}$ & $5.67 \pm 0.33 \mathrm{c}$ & $8.33 \pm 0.33 \mathrm{a}$ & $4.66 \pm 0.66 \mathrm{~b}$ \\
\hline
\end{tabular}

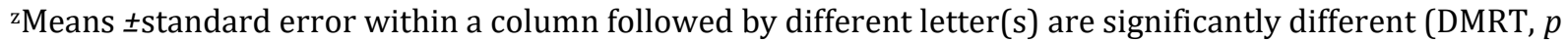
$<0.05$ ).

Table 06. Effect of pre-harvest fruit bagging on mealy bug incidence and spongy tissue of mango cv. Mollika at ripening stage

\begin{tabular}{llll}
\hline Treatments & Shelf life (days) & Mealy bugs (\%) & Spongy tissue (\%) \\
\hline Brown paper bag & $17.00 \pm 0.58 \mathrm{ab}$ & $0.00 \pm 0.00 \mathrm{~b}$ & $0.00 \pm 0.00 \mathrm{~d}$ \\
White paper bag & $18.00 \pm 0.58 \mathrm{a}$ & $0.00 \pm 0.00 \mathrm{~b}$ & $0.33 \pm 0.33 \mathrm{~d}$ \\
Muslin cloth bag & $16.00 \pm 0.58 \mathrm{bc}$ & $0.00 \pm 0.00 \mathrm{~b}$ & $2.00 \pm 0.58 \mathrm{c}$ \\
No bagging & $15.00 \pm 0.58 \mathrm{c}$ & $25.00 \pm 0.58 \mathrm{a}$ & $3.00 \pm 0.58 \mathrm{a}$ \\
\hline
\end{tabular}

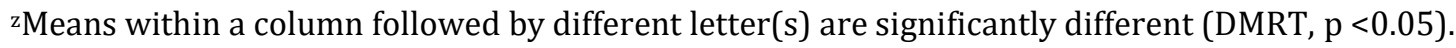

Fruits of white paper bag were free from mealy bugs, whereas fruits of brown paper bag werefree from spongy tissue. The maximum incidence of mealy bugs (25\%) and spongy tissue content (3.00\%) wasrecorded in control. Bagging modified the microenvironment near fruit especially in respect to temperature andhumidity. The longershelf life of bagged fruits indicated that the effect of bagging persisted after ripening. Bagging provided physicalbarrier between fruit and pests. The spongy tissue disorder is associated with convective heat and exposure of fruit to sunlight (Om and Prakash, 2004). Bagging provides protection against both which helpedin reducing occurrence of spongy tissue in fruits. In mango cv. Keitt white paper bags at approximately 100 daysbefore harvest reduced anthracnose and stem end rot (Hofman et al., 1997).

\section{Conclusion}

Pre-harvest fruit bagging has emerged as a novel technology in practice, which is simple, grower friendly, safe and beneficial for production of quality fruits. Brown paper bag showed best performance for fruit retention, days required for harvesting, fruit length, total soluble solids, pulp weight, pulp stone ratio and $\beta$-carotene contentof fruit. White paper bag contributed best performance for citric acid content, reducing sugar and total sugar content where as muslin cloth bag increases fruit diameter and stone weight. Bagging had significant effect on mealy buginfestation. Bagging fruits have a good shelf life which is important criteria for exportable mango. Therefore, farmers might be used this technology for commercial mango cultivation for fulfill the demand of quality mango in country and abroad.

\section{Acknowledgement}

This work was supported by funds (BS 165) The Ministry of Science and Technology (MOST), under special allocation for science and technology, Government of the People's Republic of Bangladesh. 


\section{References}

[1]. Amarante, C., Banks, N. H. and Max, S. (2002). Preharvest bagging improves packout and fruit quality of pears (Pyrus communis). New Zealand Journal of Crop Hortcultural Science, 30, 9398. https://doi.org/10.1080/01140671.2002.9514203

[2]. Amerine, M. A., Pangborn, R. M. and Rocssler, E. B. (1965). Principles of sensory evaluation of food. London: Academic Press.

[3]. Amin, M. and Hanif, M. (2002). Cultivation of Mango in Dera Ismail Khan. Agri. Res. Institute, Ratta, DI Khan, pp.1-18.

[4]. AOAC, 17th edition, (2000). Official method 920.183 (b) sugars (reducing sugar) in Honey/ I. S. I. Hand book of Food Analysis (part 2). pp. 36.

[5]. AOAC (2004). Official Methods of Analysis. Association of Official Analytical Chemists (12 ${ }^{\text {th }}$ Ed.) Washington, D. C.

[6]. Awad, M. A. (2007). Increasing the rate of ripening of date palm (Phoenix dactylifera L.) cv. Helali by preharvest and postharvest treatments. Postharvest Biol. Technol. 43, 121-127.

https://doi.org/10.1016/j.postharvbio.2006.08.006

[7]. Bayogan, E. R. V., Campeon, R. T. and Esguerra, E. B. (2006). 'Carabao' mango harvest quality and production practices andproblems of growers in Davao Oriental, Philippines. ISHS Acta Horticulturae, 699, 103-109. https://doi.org/10.17660/ActaHortic.2006.699.10

[8]. Bentley, W. J. and Viveros, M. (1992). Brown-bagging GrannySmith apples on trees stops codling moth dam-age. California Agricultue, 46, 30-32.

[9]. Bhuyan, M. A. J., Uddin, M. N., Mortuza, M. G., Islam, M. S. and Sarker, B. C. (2003). Catalogue on mango germplasm. Volume 1 (Indigenous Collection). Horticulture Research Centre, Bangladesh Agricultural Research Institute, Joydebpur, Gazipur and IPGRI-ADB-TFT Project Publ. p. 117.

[10]. Chonhenchob, V., Kamhangwong, D., Kruenate,J., Khongrat, K., Tangchantra, N., Wichai, U.and Singh, S. P. (2011). Pre-harvest bagging with wavelength-selective materials enhances development and quality of mango (Mangifera indica L.) cv. namdokmai. Journal ofScience and Food Agriculture, 91, 664-671. https://doi.org/10.1002/jsfa.4231

[11]. Haldankar, P. M., Parulekar, Y. R., Alwala, K., Kad, M. S., Shinde, S. M. and Lawande, K. E. (2015). Studies on influence of bagging of fruits at marble stage on quality of mango cv. alphonso. Journal of Plant Studies, 4, 12-20. https://doi.org/10.5539/jps.v4n2p12

[12]. Haq, I. U. and Rab, A. (2012). Characterization of physico-chemical attributes of litchi fruit and its relation with fruit skin cracking. Journal of Animal and Plant Science, 22, 142-147.

[13]. Hiratsuka, S., Yokoyama, Y., Nishimura, H., Miyazaki, T. and Nada, K. (2012). Fruit photosynthesis and phosphoenol pyruvate carboxylase activity as affected by lightproof fruit bagging in Satsuma mandarin. Journal of American Society of Horticulticultural Science, 137, 215-220.

[14]. Hofman, P. J., Smith, L. G., Joyce, D. C., Johnson, G. L. and Meiburg, G. F. (1997). Bagging of mango(Mangifera indicacv. 'Keitt') fruit influences fruit quality and mineral composition. Postharest Biological Technology, 12, 83-91. https://doi.org/10.1016/S0925-5214(97)000392

[15]. Hongxia, W., Wang, S. B, Shi, S. Y., Ma, W. H., Zhou, Y. G. and Zhan, R. L. ( 2009). Effects of bagging on fruit quality in Zill mango. Journal of Fruit Science, 26, 644-648.

[16]. Joshi, G. D. and Roy, S. K. (1988). Influence of maturity, transport and cold storage on biochemical composition of Alphonso mango fruit. Journal of Maharashtra Agricultural Universities, 13(1), 12-15.

[17]. McHenry, E. W. and Graham, M. (2013-2019). Observation on the estimation of ascorbic acid by filtration. Biochemistry Journal, 29(9).

[18]. Moffett, Jr. T. M. and Pater, Dr. E. (2007). Determination of Citric Acid in Fruit Juice. SUNY Plattsburgh.

[19]. Nagata, M. and Yamashita, I. (1992). Simple method for simultaneous determination of chlorophyll and carotenoids in tomato fruit. Journal of Japanese Society of Food Science and Technology, 39,925-928. https://doi.org/10.3136/nskkk1962.39.925

[20]. Om, P. (2004). Diseases and disorders of Mango. In diseases of fruits and vegetable, diagnose and management. The Netherlands: Kluwer Academic Publishers.1. p. 596. 
[21]. Rathore, H. A, Masud, T, Sammi, S. and Soomro, A. H. (2007). Effect of storage on physicochemical composition and sensory properties on mango (Mangifera indica L.) variety dasehari. Pakistan Journal of Nutrition, 6,143-148. https://doi.org/10.3923/pjn.2007.143.148

[22]. Santini, A., Romano, R., Meca, G. and Raiola, A. (2014). Antioxidant activity and quality of apple juices and puree after in vitro digestion. Journal of Food Research, 3, 1-50.

https://doi.org/10.5539/jfr.v3n4p1

[23]. Sharma, R. R., Pal, R. K., Asrey, R., Sagar, V. R., Dhiman, M. R. and Rana, M. R. (2013). Pre-harvest fruit bagging influences fruit color and quality of apple cv. Delicious. Agricultural Science, 4(9), 443-448. https://doi.org/10.4236/as.2013.49059

[24]. Sharma, R. R., Reddy, S. V. R. and Jhalegar, M. J. (2014). Preharvest fruit bagging a review. Journal of Horticultural Science andBiotechnology, 89, 101-113.

https://doi.org/10.1080/14620316.2014.11513055

[25]. Singh, B. P., Singh, R. A., Singh, G. and Killadi, B. (2007). Response of bagging on maturity, ripening and storage behaviour of winter guava. Acta Horticulture, 735, 597-601. https://doi.org/10.17660/ActaHortic.2007.735.77

[26]. Singh, H. (1996). Mango. ICAR. New Delhi, India.

[27]. Song, G. C. and Song, N. H. (1993). Study of water status in relation to berry splitting in "Kyoho" grape. RDA Journal of Agricultural Science and Horticulture, 35, 484-489.

[28]. Wang, G., Xia, R., Zeng, X. and Hu, L. (2006). Effects of bagging on pigment, sugar and endogenous hormone contents of Cara Cara orange flesh. Journal of Applied Ecology, 17, 256260.

[29]. Watanawan, A., Watanawan, C., and Jarunate, J. (2008). Bagging 'Nam Dok Mai' mango during development affects color and fruit quality. Acta Horticulturae, 787, 325-330. https://doi.org/10.17660/ActaHortic.2008.787.40

[30]. Yang, W. H., Zhu, X. C., Bu, J. H., Hu, G. B., Wang, H. C. and Huang, X. M. (2009). Effects of bagging on fruit development and quality in cross-winter off-season longan. Scientia Horticulturae, 120, 194-200. https://doi.org/10.1016/j.scienta.2008.10.009

[31]. Zhao, J. J., Wang, J. B., Zhang, X. C., Li, H. L. and Gao, Z. Y. (2013). Effect of bagging on the composition of carbohydrate, organic acid and carotenoid contents in mango fruit. Acta Horticulture, 992, 537-554. https://doi.org/10.17660/ActaHortic.2013.992.66

[32]. Zhou, J., Zhong, G., Lin, Z. and Xu, H. (2012). The effects of bagging on fresh fruit quality of Canarium album. Journal of Food and Agricultural Environment, 10 (1), 505-508.

\section{HOW TO CITE THIS ARTICLE?}

\section{Crossref: https://doi.org/10.18801/jbar.150117.153}

\section{APA (American Psychological Association)}

Islam, M. T., Shamsuzzoha, M., Rahman, M. S., Haque, M. M. and Alom, R. (2017). Influence of preharvest bagging on fruit quality of mango (Mangifera indica L.) cv. Mollika. Journal of Bioscience and Agriculture Research,15(01), 1246-11254.

\section{MLA (Modern Language Association)}

Islam, M. T., Shamsuzzoha, M., Rahman, M. S., Haque, M. M. and Alom, R. "Influence of pre-harvest bagging on fruit quality of mango (Mangifera indica L.) cv. Mollika". Journal of Bioscience and Agriculture Research, 15.01(2017): 1246-1254.

\section{Chicago and or Turabian}

Islam, M. T., Shamsuzzoha, M., Rahman, M. S., Haque, M. M. and Alom, R. "Influence of pre-harvest bagging on fruit quality of mango (Mangifera indica L.) cv. Mollika.". Journal of Bioscience and Agriculture Research,15 no.01(2017):1246-1254. 